\title{
Pond Filling and Its Causes in Pabna District in Bangladesh
}

\author{
Mst. Rupali Akhtar ${ }^{1}$, Anamika Paul ${ }^{2}$, Md. Liton Hossen ${ }^{3}, \mathrm{Md}$. Yeamin $\mathrm{Ali}^{2}, \mathrm{Md}$. \\ Fozla Rabbi ${ }^{3}$, Mst.Nargis Parveen ${ }^{5}$, Mohammad Ali Oakkas ${ }^{4}$, Md. Anower \\ Hossain $^{6}$, Akib Javed ${ }^{7}$, Mohammed Alauddin Al-Agad ${ }^{8}$, Dr. Md. Farhad uddin ${ }^{9}$, \\ Md. Atiqur Rahman ${ }^{2}$,Mahfuza Khanom Sheema ${ }^{2}$, Abdulla-Al Kafy ${ }^{10}$, Md. \\ Shahariar Sarker ${ }^{7}$, Mardia $^{7}$ \\ ${ }^{I}$ DepartmentofPoliticalScience, RajshahiUniversity, Bangladesh \\ ${ }^{2}$ InstituteofEnvironmentalScience, RajshahiUniversity,Bangladesh \\ ${ }^{3}$ DepartmentofAnthropology, RajshahiUniversity, Bangladesh \\ ${ }^{4}$ DepartmentofSocial Work,Shahajalal University of Science and Technology, Sylhet,Bangladesh \\ ${ }^{5}$ DepartmentofSociology, North Bengal InternationalUniversity, Rajshahi,Bangladesh \\ ${ }^{6}$ Departmentof IslamicHistoryandCulture, RajshahiUniversity,Bangladesh \\ ${ }^{7}$ DepartmentofGeographyandEnvironmentalStudies, RajshahiUniversity,Bangladesh \\ ${ }^{8}$ Department of Sociology, Narsingdi Govt. College, Narsingdi, Bangladesh \\ ${ }^{9}$ Veterinary Surgeon and in Charge of Rajshahi Zoo, City Health Department, Rajshahi City Corporation, \\ Bangladesh \\ ${ }^{10}$ Department of Urban and Regional Planning, Rajshahi University of Engineering \&Technology, Bangladesh
}

\begin{abstract}
The study aimed at understanding the phenomenon of filling up ponds in Pabnadistrict and to find out the causes for pond filling. It also recommends policies to conserve ponds in Pabna district. This study makes an attempt to find out how urbanization leads to filling up the ponds and analyze the trends of pond fill during past 30 years. In 1986 total pond area in this district was 750.06 hectares- about $0.32 \%$ of the total land area. But in 2016, it was reduced to 562.03 hectares (about 0.24\% of total land area). Urbanization, greed for land leading to encroachment were considered to be the main reasons for filling up ponds in the district, basically all the causes related with urbanization. This trend in pond filling making the drainage system of Pabnadistrict vulnerable increases urban flooding and water logging and temperature of the district area rises to an unexpected extent.
\end{abstract}

Keywords: Pabna, Pond Filling, Urbanization, Causes.

\section{Introduction}

Ponds are small $\left(1 \mathrm{~m}^{2}\right.$ to about $\left.5 \mathrm{ha}\right)$, man-made or natural shallow water bodies which permanently ortemporarily hold water [1]. Ponds may naturally rise in floodplains as part of a river system, or they may be somewhat isolated depressions (examples include vernal pools and prairie potholes). Usually they contain shallow water with marsh and aquatic plants[2]. The type of life in a pond is generally determined by a combination of factors including water level regime (particularly depth and duration of flooding) and nutrient levels.Other factors may also be important, including presence or absence of shading by trees, presence or absence of streams, effects of grazing animalsand salinity[3].

Ponds are important place for biodiversity.Collectively, they support more species, and more scarce species, than any other freshwater habitat [4].Ponds are critical to our biodiversity and the protection of ponds is essential. Before examining the effects of the loss of ponds, it is important to give a definition of ponds and provide an overview of what they are, where ponds exist, and why ponds are important. Except Antarctica, ponds can be found nearly everywhere; natural or man-made. Like other developing countries, Bangladesh experienced a fast increase of urban population in the recent decades. At present $28.4 \%$ of total population live in urban area (2011) and annual rate of urbanization is 2.96\% [5]. In the last five decades, a total 4000 ponds have been filled because of the indiscriminate earth-dumping and unplanned urbanization. In 1961, there were 4238 ponds, canals, and wetlands in Pabnadistrict. The number of ponds decreased to 2271 in 1981 and 729 in 2000. In 2014, Pabnadistrict has only 214 water bodies [6].A district like Pabna, located the alluvial river plains, has many ponds in and around.The study area can be severely suffered from ecological degradation through rapid urbanization and harmful changes. Several researches have conducted about water bodiesbefore.None of these was about the pond filling of Pabnadistrict. The present work implies upon the trend of pond fill in Pabnadistrict and its impact on environment. The studydepends on some remote sensing data and primary data. Based on those data, we also analyze the trend of pond fill in the study area, identify its causes and reveal its 
effect on the environment.This study aimed to understand the causes of pond filling and explore the rate of pond filling in context Pabnadistrict.

\section{Materials and Methods}

The Pabnadistrict is one of the oldest cities of Bangladesh. Pabna is located in the north-west of the country and has an estimated population of 2,523,179 people [7]. Its total area is $2,371.50 \mathrm{~km}^{2}$ and situated on the northern banks of river Padma. It'slocation by geographical co-ordinations is $23.50^{\circ} \mathrm{N}$ latitude to $24.20^{\circ} \mathrm{N}$ latitude and $89.00^{\circ}$ Elongitude to $89.45^{\circ} \mathrm{E}$ longitude [8].The present work was conducted using both primary and secondary data.The primary data were collected from a structured questionnaire, and interviews and focus group observations. The secondary data were collected from remote sensing database. The questionnaire survey was conducted based on random sampling which includes 100 respondents. The primary data were analyzed by IBM SPSS 20 software and remote sensing data were analyzed by Arcgis 9.3 software and IDRISI Selva.

This remote sensing imagery taken from US geological survey. All maps are prepared by Image classification method. The Raster Image of Pabna District was Clipped by the area of actual Pabna district. Than the area was classified into four categories by ISO Cluster Unsupervised classification like Water body,Settlement, Open space and Vegetation area respectively. After that simply digitize the Pabna area Boundary and small area of water body which represents ponds. The Ponds fill up map of Pabna districtfrom 1986-2016 was produced by simply identify the ponds area which was filled up in ten years' interval time.

\subsection{Ponds of Pabna Districtin 1986}

\section{Results and Discussion}

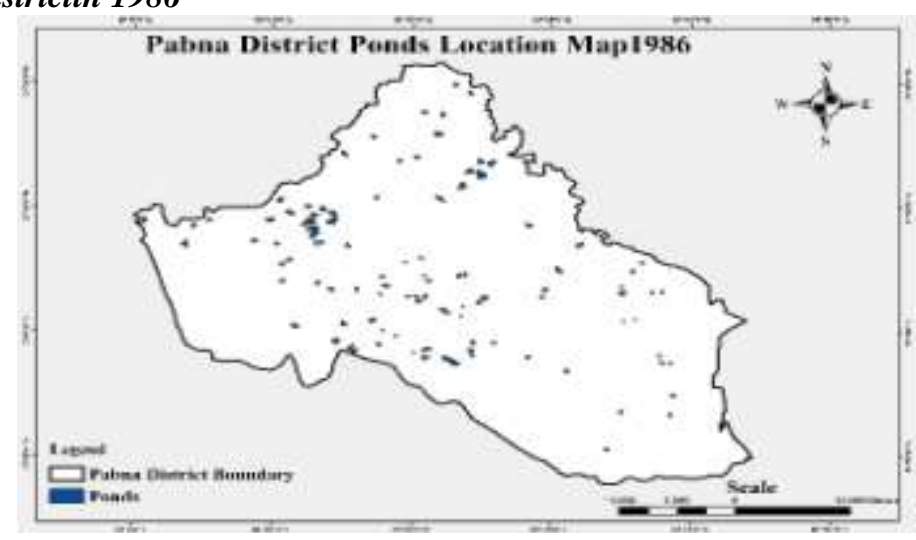

Figure 1 Ponds of Pabna District in 1986.

Table 1 Land Use Distribution in PabnaDistrict, 1986

\begin{tabular}{|l|l|l|}
\hline Land use categories & Area (in hectares) & Percentage (\%) \\
\hline Pond & 750.06 & $0.32 \%$ \\
\hline Total Land & 237613.20 & 100 \\
\hline
\end{tabular}

Source: Land use analysis map in 1986.

Table1shows, that in 1986, the total land use area was found about 237613.20 hectares. The pond area was 750.06 hectares $(0.32 \%$ of the total area) and the actual land area comprises build-up section, vegetation and the fallow land. So the Table clearly indicates that the area of the ponds was not adequate in $1986(0.32 \%$ of the total area). Which is decreasinggradually with time. 


\subsection{Ponds of Pabna District in 1996}

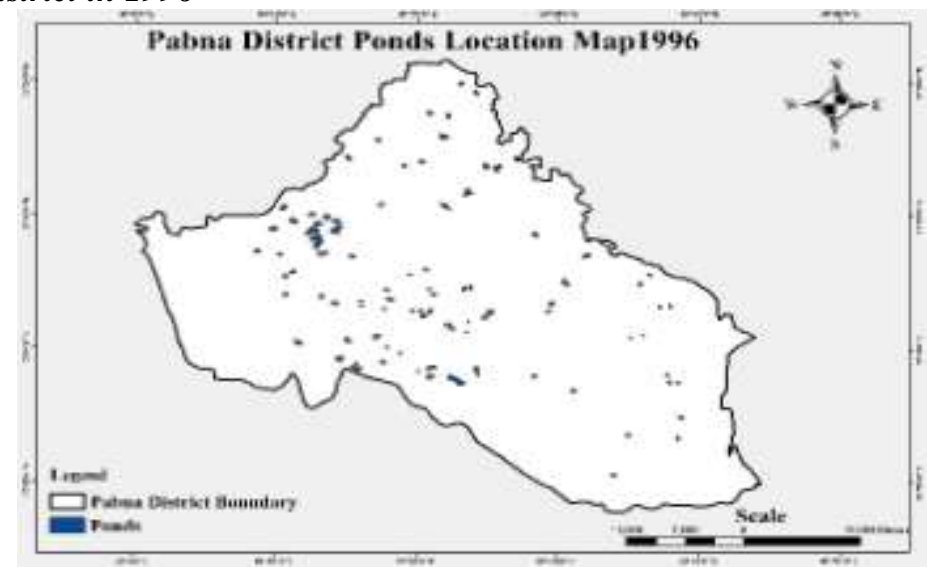

Figure 2.Pond of Pabna District in 1996.

Table 2 Land Use Distribution in Pabna District, 1996

\begin{tabular}{|c|c|c|c|}
\hline Land use categories & Area (in hectares) & Percentage (\%) & $\begin{array}{c}\text { Change in Percentage } \\
\text { (Comparison with 1986) }\end{array}$ \\
\hline Pond & 668.62 & $0.28 \%$ & $10.86 \%<$ \\
\hline Total Land & 237613.20 & 100 & \\
\hline
\end{tabular}

Source: Land use analysis map in 1996.

In 1996, Table 2 shows that, the total land area was found about 4712.99 hectares where the ponds area was 668.62 hectares $(0.28 \%$ of the total area) and the actual land area such as build-up section, vegetation and the fallow land. The results show that $0.32 \%$ ponds were filled in 1986 . That decreased to $0.28 \%$ in 1996 . Hence the total loss of ponds area is $10.86 \%$ in last 10 years.

\subsection{Ponds of Pabna District in 2006}

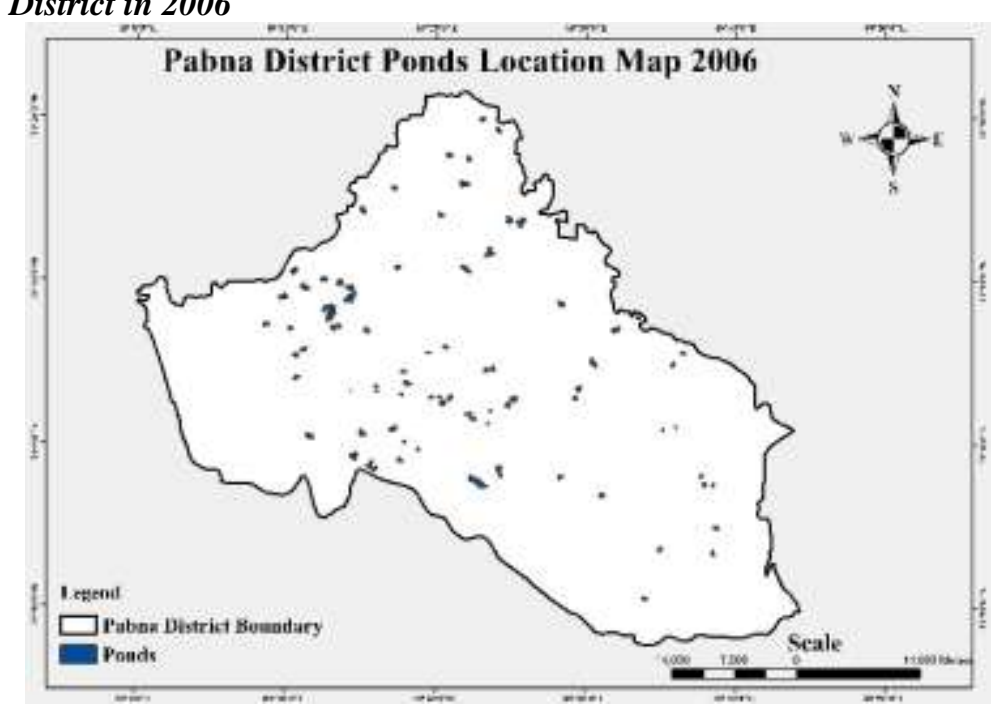

Figure 3.Pond of Pabna District in 2006.

Table 3 Land Use Distribution in Pabna District, 2006

\begin{tabular}{|c|c|c|c|}
\hline Land use categories & Area (Hectares) & Percentage (\%) & $\begin{array}{c}\text { Change in Percentage } \\
\text { (Based on 1986) }\end{array}$ \\
\hline Pond & 642.15 & $0.27 \%$ & $14.39 \%$ \\
\hline Total Land & 237613.20 & 100 & \\
\hline
\end{tabular}

The Table 3 shows, in 2006, pond area was 642.15 hectares $(0.27 \%$ of the total area) and the actual land area was237613.20hectares. In above data we see that, in 1986,there were $0.32 \%$ of pond area. It decreased to $0.28 \%$ in 1996 and $0.27 \%$ in 2006.It's mean within 20-yearpond lost $14.39 \%$ of its area. 


\subsection{Ponds of Pabna District in 2016}

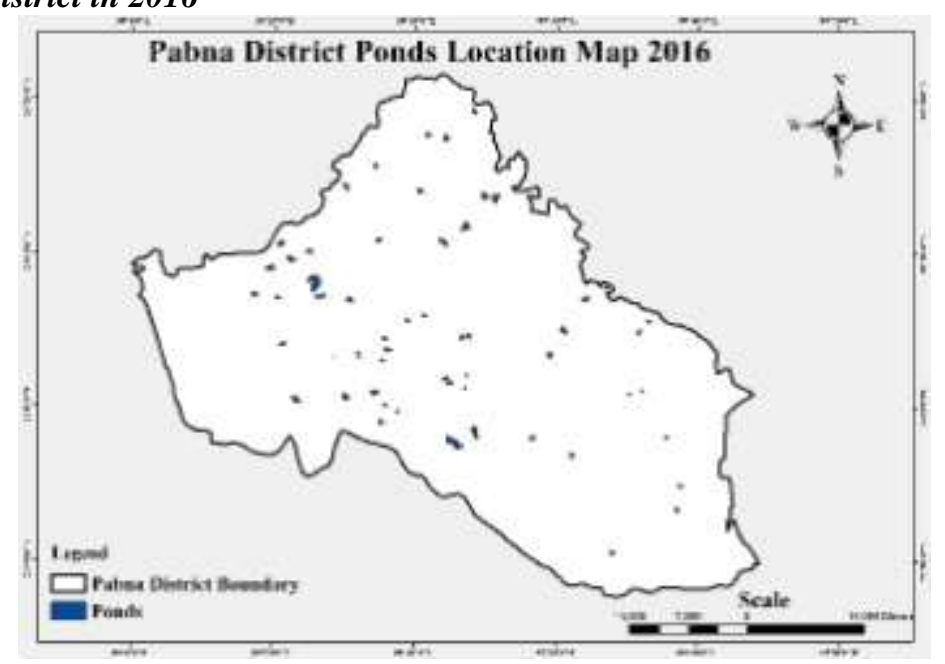

Figure 4.Pond of Pabna District in 2016.

Table 4 Land Use Distribution in Pabna District, 2016

\begin{tabular}{|c|c|c|c|}
\hline Land use categories & Area (Hectares) & Percentage (\%) & $\begin{array}{c}\text { Change in Percentage } \\
\text { (Comparably from 1986) }\end{array}$ \\
\hline Pond & 562.03 & $0.24 \%$ & $25.07 \%$ \\
\hline Total Land & 237613.20 & 100 & \\
\hline
\end{tabular}

In 2016, latest data shows pond area decreased further and reached $0.24 \%$ of total land area. Based on the data of $1986,25.07 \%$ of total pond area has been lost.

Its mean, in last 30 years (1986-2016) total loss of pond is $0.08 \%$ of total land area and total one fourth of pond area been lost in last 30 years. Already Pabna is district where there is very less pond in compared to surrounding districts.

\subsection{Pond fill in Pabna District during 1986-2016}

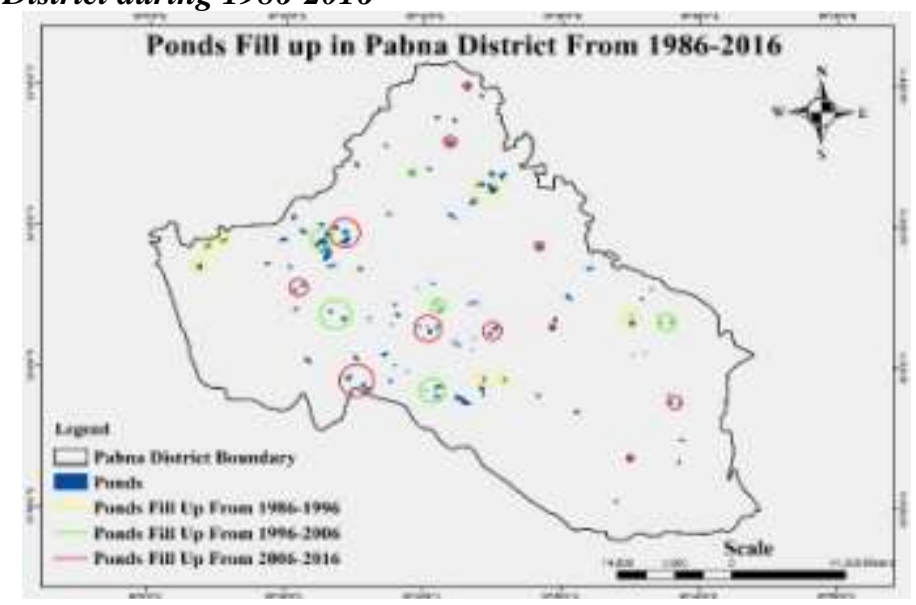

Figure 5Pond Filling Scenario of Last 30 Years

Table 5Pond area in Pabna District, 1986-2016.

\begin{tabular}{|c|c|c|c|}
\hline Year & Area (in Hectare) & Total Land (in Hectare) & Percentage (\%) \\
\hline 1986 & 750.06 & & 237613.20 \\
& 668.62 & & $0.32 \%$ \\
\hline 2006 & 642.15 & & $0.28 \%$ \\
\hline 2016 & 562.03 & & $0.27 \%$ \\
& & & $0.24 \%$ \\
\hline
\end{tabular}

Table 4 shows that, ponds area of Pabna district is decreasing gradually where the corresponding other land area are increasing with time. In 1986, the area of ponds was 750.06 hectares while in 1996, it was 668.62 hectares. That pond area further decrease to 642.15 in 2006 and even 562.03 to 2016. Its mean with in last 30 
years' ponds of Pabna loses $25 \%$ of its area. Only in last 10 years 80.12 hectares of land lost in various causes. If this trend of pond encroachment continues than within 90 years.

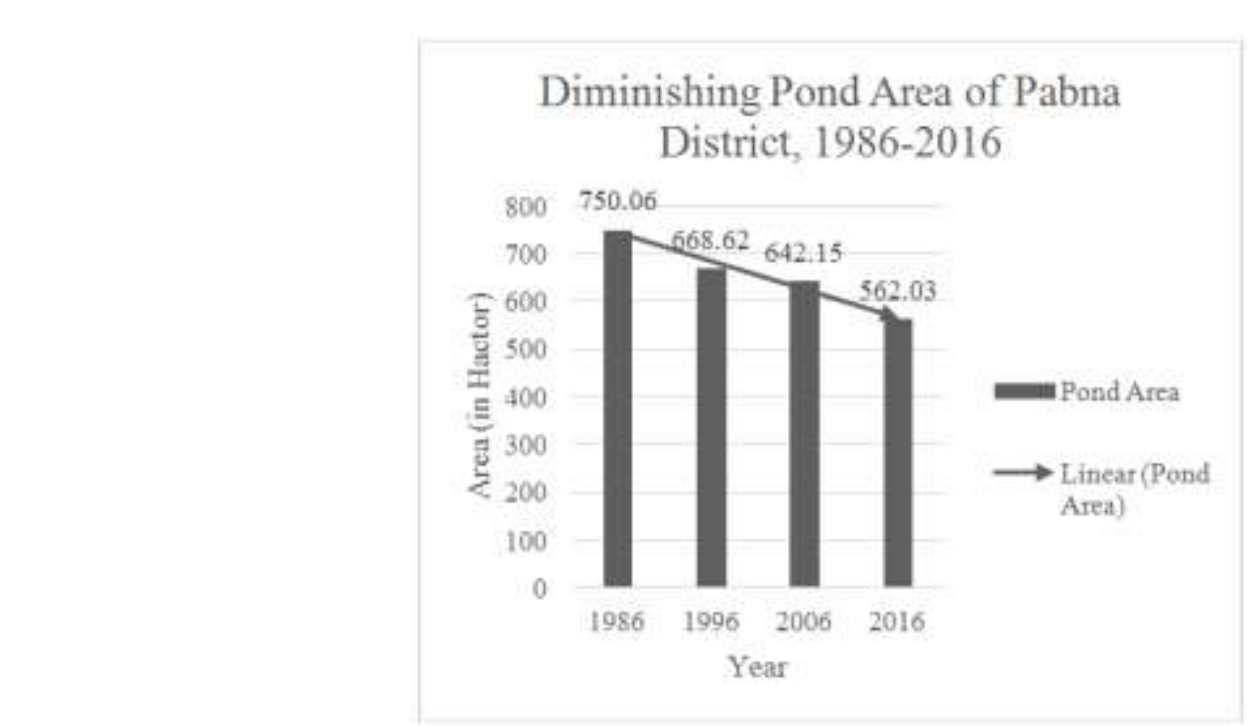

\subsection{Causes ofPond Fill}

Figure 6Trend of Pond Area Decrease, 1986-2016

In 30 years more ponds and wetlandhave been filled Pabnadistrict. Since then, extensive losses have occurred, with many of the original ponds were filled and many of them were converted to farmland. Activities resulting in pondfill loss and degradation include: urban (commercial and residential) development, agriculture, and land filling, encroachment and huge political and institutional support ignoring the rules and laws. The main causes of pond fill are shown in the fig. below.

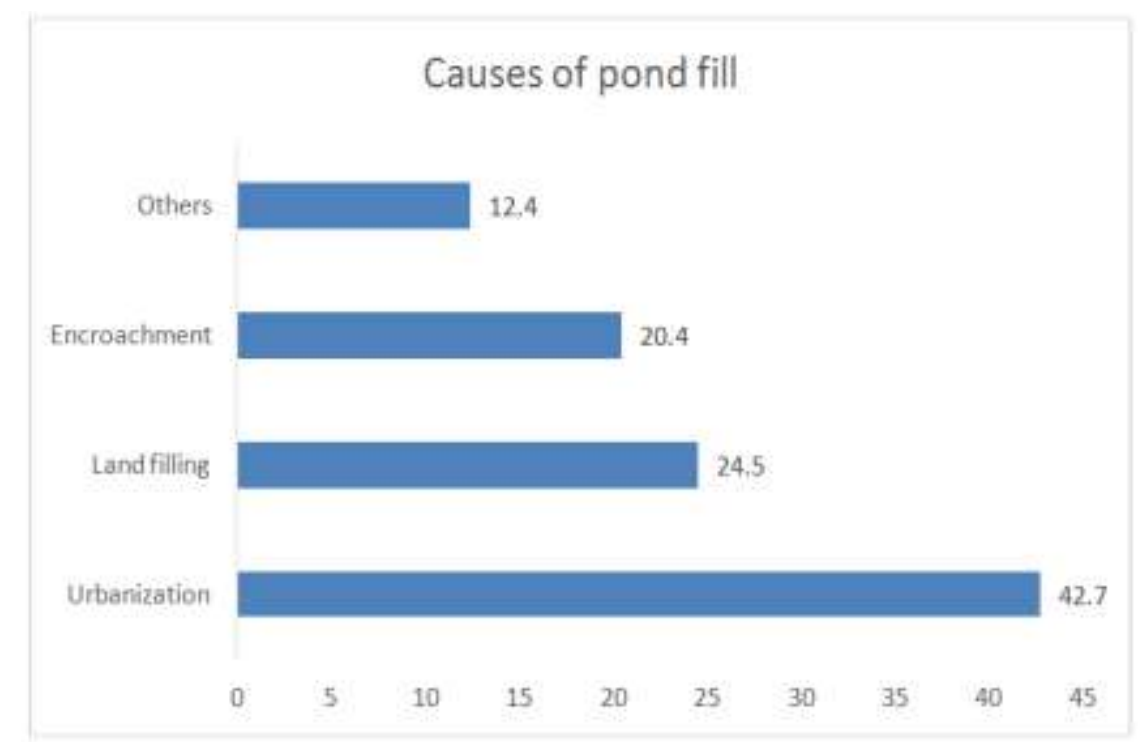

Figure 7.Sector Wise Pond Fill in Pabna District.

Fig. 7 shows that, urbanization is the main causes of diminution of pond, where urbanization causesaround $43 \%$.

\subsubsection{Urbanization}

Urbanization is a major cause of impairment of ponds. Urbanization has resulted in direct loss of pondacreage as well as degradation of ponds. Construction activities are a major source of suspended sediments that enter ponds through urban runoff. In Pabna district in 30 years, $43 \%$ of pond fill happened due to urbanization. Shopping Centre, Market, high rise building, restaurant are the main causes of pond fill in Pabna district. Mainly, increasing residential infrastructure is the main cause of pond fill here. In Pabnadistrict,different ponds have been affected by urbanization.Similarly, rapid urbanization causes pond losing in Khulna District [10]. 


\subsubsection{Land filling}

Fill in a pond occurs when earthen or other miscellaneous material is used to fill in the area of a pond and to raise the final elevation of the site. About $25 \%$ respondent said that land filling is the one of the causes for pond fill in Pabnadistrict. Land filling is the second most important causes of pond fill in Pabna district. In study area land filling occurs for different purposes. For example: most of the time the owners filled their pond for house building and residential building purposes. Because from pond an owner gets nothing but if he totallyfills it and makes some construction or building, then that person gets huge amount of money.

\subsubsection{Encroachment}

Pond encroachment is very common practice in Pabnadistrict. The first step of encroachment is to build structures along the surroundings of ponds and further out on the ponds itself. To do this, rows and bamboo posts are positioned and fixed on the water body bed along the bank and extending into the main body of the pond. Then huts and shops are built on these stilts. The owners of these structures are then start reclaiming land by earth fills and dumping garbage. Most of the respondents said that encroachment mostly happens where pond owner has his house near the pond. From the survey data it can be said that $20 \%$ pond fill happens due to encroachment.

\subsubsection{Others}

Pond filling has some other reason as well. Such as, political pressure in unlawful land grabbing, unplanned urbanization and district expansion, unplanned constructing of government building etc.

\section{Recommendations}

There should be taken necessary measures to conserve ponds and develop scenic viewaround the ponds to create more attraction to the district dwellers. Thestudy may conclude some recommendations in order to stop pond fill in Pabna and help to make an environment friendly district.

1. Law should strictly maintain for every community people and organization.

2. Social awareness should be built and some awareness program should be arranged to stop pond fill.

3. Environmental issue related story should be included in higher secondary school syllabus, which would help to grow consciousness about environment among children.

4. Local government could play an important role in pond fill restriction.

\section{Conclusion}

In 30 years 188.03 hectors area of ponds in Pabnadistrict has been filled. There will be no pond in Pabnadistrict area if the current trend continues for next 90 years. The study observes that the main causes for pond fill of Pabnadistrict are urbanization, encroachments, land filling etc. The ultimate effects of the pond fill are biodiversity loss, environmental degradation, urban flooding, and loss of water resource. There should be taken necessary measures to conserve ponds and develop scenic viewaround the ponds to create more attraction to the district dwellers. The conservation of ponds is crucial for Pabna district to keep the ecological balance, especially to reduce the urban flooding. The recommends of the study would help protect ponds from fill and create an environmental friendly district.

\section{References}

[1] L. De Meester, S. Declerck, R. Stoks, G. Louette, F. Van deMeutter, T. De Bie, E. Michels and L. Brendonck, Ponds and pools as model systems in conservation biology,ecology and evolutionary biology, Aquatic Conservation: Marine and Freshwater Ecosystems, 15(6), 2005, 715-726.

[2] J. Clegg, The New Observer's Book of Pond Life (Frederick Warne, 1986). p. 460. ISBN 0723233381.

[3] Paul A. Keddy, Wetland Ecology: Principles and Conservation (Cambridge University Press, 2010). ISBN 0521739675

[4] R. Céréghino, J. Biggs, B. Oertli, and S. Declerck, The Ecology of European ponds: defining the characteristics of a neglected freshwater habitat,Hydrobiologia, 597(1), 2008, 1-6.

[5] CIA World Factbook, 2015

[6] Rahman, Md. Haabibur (2014), Pond Filling Plagues Rajshahi District, Dhaka Tribune, September 2, 2014

[7] BBS, Population and Housing Census-2011, Bangladesh Bureau of Statistics.

[8] Banglapedia, CD ROM edition, version-1

[9] Mahbub Siddik (2014) "Heritage Rajshahi and Environmental Committee" Daily Prothom-Alo 24 April 2014.

[10] K. Halder, K.R. Rahman, S. Azim, Rapid Urbanization and Impact on Urban Ponds: An Anatomy of Khulna District Bangladesh, Proc. Canadian Association of Geographer's Annual Conference, Canada, 2010

[11] E. Allen and C. A. Seaman, Likert Scales and Data Analyses, Quality Progress,40(7), 2007, 64-65.

[12] Global Land Cover Facility (GLCF); acquired from, http://glcf.umd.edu/data/

[13] WHO (Editor); UNICEF (Editor) (2010): Progress on Sanitation and Drinking-Water. 2010 Update. Geneva: World Health Organisation (WHO) / New York: UNICEF 